\title{
Culturable airborne bacteria and isolation of methicillin-resistant coagulase-negative staphylococci from outdoor environments on European side of Istanbul, Turkey
}

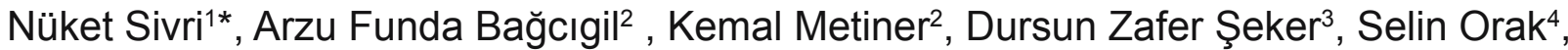 \\ Sevgi Güneş Durak ${ }^{5}$, Vildan Zülal Sönmez ${ }^{1}$ \\ Istanbul University, Turkey \\ ${ }^{1}$ Engineering Faculty, Environmental Engineering Department \\ ${ }^{2}$ Faculty of Veterinary Medicine, Department of Microbiology \\ Istanbul Technical University, Turkey \\ ${ }^{3}$ Civil Engineering Faculty, Department of Geomatics Engineering \\ ${ }^{4}$ Çevre Yapı Arıtma Sistemleri, Nilüfer Ticaret Merkezi Yaylalı Sok. No:7 Nilüfer, Bursa, Turkey \\ ${ }^{5}$ Yıldız Technical University, Turkey \\ Civil Engineering Faculty, Environmental Engineering Department \\ *Corresponding author's e-mail: sivrin@gmail.com
}

Keywords: Antimicrobial resistance, Culturable airborne bacteria, European side of Istanbul, GIS, Staphylococcus sp.

\begin{abstract}
This study is aimed to investigate culturable airborne bacteria concentrations and the composition of methicillin-resistant staphylococci in eleven different locations on the basis of specific activities conducted within different parts of the European side of Istanbul. The highest bacterial levels were observed at the Bakirkoy station (1 $\left.100 \mathrm{CFU} / \mathrm{m}^{3}\right)$ while the second highest levels were found at the Bahcelievler station $\left(1040 \mathrm{CFU} / \mathrm{m}^{3}\right)$ in October; the lowest levels $\left(10 \mathrm{CFU} / \mathrm{m}^{3}\right)$ were measured at other different stations (Atakoy, Yesilkoy). Fifteen methicillin-resistant isolates [Staphylococcus hominis $(\mathrm{n}=11)$, S. cohnii $\mathrm{spp}$. cohnii $(\mathrm{n}=2)$, S. sciuri $(\mathrm{n}=1)$, S. capitis spp. capitis $(n=1)]$ were identified. The disc diffusion method was used to identify the antimicrobial resistance of these isolates, it was observed that the most common resistance was to penicillin $(\mathrm{P})(\mathrm{n}=11)$, doxycycline $(\mathrm{DO})(\mathrm{n}=4)$ and tetracycline $(\mathrm{T})(\mathrm{n}=5)$. None of the isolates was resistant to imipenem, amoxicillin/clavulanic acid, vancomycin (IPM, AMC, VA). However, multiple antimicrobial resistance was found to be $26.7 \%$. The results of this study revealed the importance of isolated methicillin-resistant staphylococci in the stations with densely active human population and traffic, for public health. As a result, the importance of resting along known shorelines, where culturable airborne bacteria concentrations are much lower, and its importance for human health have been emphasized.
\end{abstract}

\section{Introduction}

Bioaerosols consist of all airborne particles of biological origin, bacteria, fungi, fungal spores, viruses, and pollen and their fragments, including various antigens. Particle sizes may range from aero-dynamic diameters of 0.5 to $100 \mu \mathrm{m}$. Aerosol particles of biological origin (cells, cell fractions or organic matter of animal, plant and microbial origin) form a significant portion of atmospheric aerosols, sometimes numerically reaching close to $50 \%$ of all aerosol particles (Mandal and Brandl 2011). The most important factor in the transmission of infectious diseases via aerosol is the microbial quality of the air of the environment we are in. For this reason, examining the bacteriological contents of the air quality in mutually shared areas, completing the missing links that epidemiologically play a role in various diseases, determining the risk ratio and taking precautionary measures to be used in preventive medicine are among the main efforts that can be used as supporting information (Aydogdu and Asan 2008, Aydogdu et al. 2010, Karwowska et al., 2013). Airborne bacteria can have important effects on human health and the productivity of managed and natural ecosystems. For example, bacteria can cause allergic asthma and seasonal allergies, diseases which are increasingly prevalent in developed countries. Despite their abundance and likely importance, only a limited understanding of the quantities and types of bacteria is acquired in the atmosphere (Bowers et al. 2011). With recent advances in high-throughput sequencing, one can now describe the dynamics of airborne bacterial populations (Brodie et al. 2007, Bowers et al. 2009) and determine possible sources of bacteria in the atmosphere, building a more comprehensive understanding of those bacteria found in the atmosphere and the control of their populations (Bowers et al. 2010).

The genus Staphylococcus has minimum 40 species being ubiquitous and is found as a part of the normal flora in soil, water, 
skin and mucous membranes of humans and warm-blooded animals. Staphylococcus aureus, S. intermedius are among the most commonly known species in both human and animal medicine. Despite its pathogenicity, $S$. aureus is available on the skin and mucous membranes of humans and animals and also can be found as environmental contaminants. For a long time, it has been believed that this species is the only pathogen in this genus, while the coagulase negative Staphylococcus species (CoNS) has been expected to be saprophytic or rarely pathogenic. However, today, many clinical findings of CoNS have been reported, especially in people with suppressed immune systems (Huebner and Goldmann 1999, Shiomori et al. 2002, Szewczyk et al. 2003, Abulreesh and Organjii 2011, Bagcigil et al. 2012).

Within more than 80 years from the introduction of antibiotics, not only have the mortality rates decreased due to staphylococcal infections, specifically $S$. aureus, but also the resistances against antimicrobial agents have developed. While newly developed antibiotics are initially effective on $S$. aureus strains, resistance has developed over time due to the irregular use of antibiotics. The most recent example is methicillin resistance (Shiomori et al. 2002). While studies of methicillin-resistant staphylococci (MRS) are frequently conducted in hospital settings (Roberts et al. 1998, Simor et al. 2002, Skoog 2006, Bagcigil et al. 2012), air quality studies covering both indoor and outdoor air quality are quite new as a topic. In Turkey, while there are studies that focus on bacterial contamination in institutions that provide health care services, such as hospitals, clinics, and private practices (Sarica et al. 2002, Aydogdu et al. 2005, Aydogdu and Asan
2008, Aydogdu et al. 2010, Bagcigil et al. 2012), there is a lack of studies that are based on long-term observations as well as studies that examine outdoor facilities used on a daily basis (Mentese et al. 2009, Mentese et al. 2012). There is no other study about outdoor air quality based on culturable bacteria level in Turkey. The only study based on bioaerosol levels in the urban atmosphere of Ankara Province has been performed by Mentese et al. (2009), hence this is the first study on outdoor air quality and antimicrobial susceptibilities of methicillin-resistant staphylococci in Istanbul in the literature.

The aim of this study was to visualize changes in culturable airborne bacteria concentrations using GIS analysis on the basis of air samples obtained from the populated and widely used outdoor settings located on the European side in Istanbul. In addition, this study also aimed to determine distribution of methicillin-resistant staphylococci that are important for public health and their antimicrobial susceptibilities. Bacteriological air quality and current risk table on staphylococcal contamination has also been presented. At the end of the study, attempts were made to determine changes in coastal and central locations as well as potential threats.

\section{Materials and Methods}

\section{Sampling area}

In this study, outdoor air samples of frequently used locations (Table 1) were collected from 11 stations (Figure 1) on the European side of Istanbul. Samples were obtained in each month during the period of a year, from January 2009 to the end of December 2009.



Fig. 1. Sampling stations on the European side of Istanbul 
In this study, only one region of the European side (two regions in this side) was selected as the study area that covers the heart of the city known as the historical centre. For that reason, the European side which comprises the districts with the most dynamic nature and the most prominent differences of ecologic characteristics in Istanbul was selected as the sampling area due to the fact that the main laboratories in which the studies were conducted are located in European side as well. The information obtained on different ecologic characteristics of stations by means of various projects performed in coastal area for 8 years brought significant contributions to selection and optimization of the stations, determination of sampling period and formation of research teams. The first sampling area ranges along the shoreline between Avcilar and Zeytinburnu districts. Six sampling stations along the coast of the European side were randomly chosen as follows: Atakoy, Yesilkoy, Menekse, Kucukcekmece, Lagoon, and Avcilar. The second region is inland and consists of urbanized and crowded districts such as Taksim, Bahcelievler, Bakirkoy, Zeytinburnu and Eminonu. Table 1 presents all details of the sampling stations.

\section{Bioaerosol sampling}

The primary aim of the bioaerosol sampling was to conduct quantitative evaluation of the culturable airborne bacteria. The NIOSH (National Institute of Occupational Safety and Health) Method-0800 "Bioaerosol Sampling (Indoor Air)" was used to evaluate the outdoor air samples and for bacteriological evaluations, and the Microbial Air Monitoring Sampl'air ${ }^{\mathrm{TM}}$ (AES CHEMUNEX (A bioMérieux company)) was used to collect samples. This microbial air sampler has been tested by the British Health Protection Agency and validated according to ISO 14698-1 (ISO/FDIS, (14698-1) 2003). In addition to the standard enumeration of culturable airborne bacteria as $\mathrm{CFU} / \mathrm{m}^{3}$ with Plate Count Agar (PCA), we attempted to isolate Staphylococcus species to be grown on the selective media Mannitol Salt Agar (MSA) (Merck) and incubated at $37 \pm 1{ }^{\circ} \mathrm{C}, 24-48 \mathrm{~h}$.

\section{Isolation and Identification of methicillin-resistant staphylococci}

After incubation and Gram staining, presumptive staphylococci colonies were transferred onto Nutrient agar plates supplemented with $7 \%$ sheep blood to obtain pure cultures. Disc diffusion test with oxacillin $(1 \mu \mathrm{g} / \mathrm{ml})$ and cefoxitin $(30 \mu \mathrm{g} / \mathrm{ml})$ discs were performed to determine methicillin resistance among the isolates, phenotypically (NCCLS 1997, NCCLS 2004)

In order to determine the methicillin resistance genotypically, the isolates were examined via PCR (Polymerase Chain Reaction) method to identify mecA gene existence. For PCR, the DNA template was prepared by means of heating the bacterial suspensions in $50 \mu \mathrm{l}$ of distilled water for $10 \mathrm{~min}$ at $98^{\circ} \mathrm{C}$. To determine the occurrence of the mecA gene being responsible for methicillin resistance, primers developed by Geha et al. (1994) were used: mecA-F (5'-GTA GAA ATG ACT GAA CGT CCG ATA A-3') and $m e c A-\mathrm{R}$ (5'-CCA ATT

Table 1. The special characterizations of the sampling stations (Istanbul)

\begin{tabular}{|c|c|c|c|c|c|c|c|}
\hline Stations & Urban land & $\begin{array}{l}\text { Traffic } \\
\text { Load }^{1}\end{array}$ & $\begin{array}{l}\text { Green } \\
\text { Land }^{2}\end{array}$ & Location & $\begin{array}{l}\text { Daily } \\
\text { activities }^{3}\end{array}$ & $\begin{array}{l}\text { Weather } \\
\text { Conditions }\end{array}$ & $\begin{array}{l}\text { Population } \\
\text { at the year } \\
\text { of sampling* }\end{array}$ \\
\hline Atakoy & Marina, public walking areas & + & +++ & Shoreline & ++ & $\begin{array}{l}\text { Dense } \\
\text { air flow }\end{array}$ & \multirow{3}{*}{$218352^{*}$} \\
\hline Yesilkoy & Gulf, residental walking areas area & + & +++ & Shoreline & + & $\begin{array}{l}\text { Windy, } \\
\text { air flow }\end{array}$ & \\
\hline Bakirkoy & $\begin{array}{l}\text { Urbanized districts, high level storey } \\
\text { buildings }\end{array}$ & ++ & + & Inland & +++ & $\begin{array}{l}\text { Lack of air } \\
\text { circulation }\end{array}$ & \\
\hline Menekse & Public beach in summer & ++ & + & Shoreline & ++ & $\begin{array}{l}\text { Lagoon } \\
\text { effect }\end{array}$ & \multirow{3}{*}{$674795^{*}$} \\
\hline Lagoon & Industrialized areas near the lagoon & + & ++ & Shoreline & + & $\begin{array}{l}\text { Wetland } \\
\text { effect }\end{array}$ & \\
\hline Kcekmece & $\begin{array}{l}\text { Channel, highway connection, industrialized } \\
\text { areas }\end{array}$ & +++ & - & Shoreline & +++ & $\begin{array}{l}\text { Lagoon } \\
\text { effect }\end{array}$ & \\
\hline Taksim & $\begin{array}{l}\text { Urbanized and crowded districts, landmark } \\
\text { of Istanbul, transportation hub }\end{array}$ & ++ & - & Inland & +++ & $\begin{array}{l}\text { Lack of air } \\
\text { circulation }\end{array}$ & 244516 \\
\hline Zeytinburnu & $\begin{array}{l}\text { Domestic and industrial settlements } \\
\text { (high level storey buildings), hospitals }\end{array}$ & +++ & - & Inland & ++ & $\begin{array}{l}\text { Lack of air } \\
\text { circulation }\end{array}$ & 290147 \\
\hline Avcilar & $\begin{array}{l}\text { Central harbor, daily sea transport, hosting } \\
\text { more than } 10000 \text { university students }\end{array}$ & +++ & + & Shoreline & +++ & $\begin{array}{l}\text { Lack of air } \\
\text { circulation }\end{array}$ & 348635 \\
\hline Bahcelievler & $\begin{array}{l}\text { Urbanized and crowded districts, residental } \\
\text { buildings }\end{array}$ & ++ & + & Inland & ++ & $\begin{array}{l}\text { Lack of air } \\
\text { circulation }\end{array}$ & 576799 \\
\hline Eminonu & $\begin{array}{l}\text { Urbanized districts, central of financial } \\
\text { sector, busy port }\end{array}$ & +++ & - & Inland & +++ & $\begin{array}{l}\text { Lack of air } \\
\text { circulation }\end{array}$ & 433796 \\
\hline
\end{tabular}

$1+$ : $<500 \mathrm{car} / \mathrm{h} ;+++: 500-1500 \mathrm{car} / \mathrm{h} ;+++$ : $>1500 \mathrm{car} / \mathrm{h}$ (IMMAR, 2012)

${ }^{2}-:<2 \mathrm{~m}^{2}$ per person; $+: 2-5 \mathrm{~m}^{2}$ per person; ++ : 5-10 $\mathrm{m}^{2}$ per person; +++ : >10 $\mathrm{m}^{2}$ per person (IMMAR, 2013)

$3+: 09^{00}-16^{00} ;++: 07^{00}-21^{00} ;+++: 05^{00}-24^{00}$ (IMMAR, 2012)

* Joint population values are given as the stations lie within the same district (TUIK, 2013). 
CCA CAT TGT TTC GGT CTA A-3'). The following PCR conditions were used: $5 \mathrm{~min}$ at $95^{\circ} \mathrm{C}, 35$ cycles of $30 \mathrm{~s}$ at $95^{\circ} \mathrm{C}$, $45 \mathrm{~s}$ at $50^{\circ} \mathrm{C}$ and $1 \mathrm{~min}$ at $72^{\circ} \mathrm{C}$, and a final extension at $72^{\circ} \mathrm{C}$ for $10 \mathrm{~min}$ (Bagcigil et al. 2012).

Isolates with resistance to methicillin, both phenotypically and genotypically, were included in this study. Identification of the isolates was conducted by means of catalase, oxidase, oxidation fermentation, coagulase, urease, DNase tests, hemolysis, pigmentation, carbohydrate fermentation, determination of various aminoacid hydrolization features, polymyxin-B, and novobiocin and furazolidone sensitivity tests (Koneman et al. 1997).

\section{Antimicrobial susceptibility testing}

Antimicrobial susceptibilities of the methicillin resistant staphylococci were determined by the disk diffusion method in accordance with the Clinical and Laboratory Standards Institute (CLSI) standards (CLSI, 2013). The following antimicrobial disks (Oxoid) were used: ciprofloxacin $(5 \mu \mathrm{g})$, penicillin $(10 \mu \mathrm{g})$, doxycycline $(30 \mu \mathrm{g})$, imipenem $(10 \mu \mathrm{g})$, tetracycline (30 $\mu \mathrm{g})$, streptomycin $(10 \mu \mathrm{g})$, amoxicillin/clavulanic acid (20-10 $\mu \mathrm{g})$, vancomycin $(30 \mu \mathrm{g})$, gentamicin $(10 \mu \mathrm{g})$, and clindamycin $(2 \mu \mathrm{g})$ (NCCLS 1997, NCCLS 2004, CLSI 2013). Isolates with resistance to two or more classes of antimicrobial were classified as multi drug resistant (Magiorakos et al. 2012).

\section{Statistical Tools}

Different tools (GIS and Cluster Analysis) were used in order to easily follow up the changes in culturable airborne bacteria concentration by seasonal changes and the stations with different ecologic conditions; to obtain more comprehensible data and determine the difference between the stations.

The first one of these tools is Geographic Information System (GIS). GIS is basically defined as a set of software and hardware which can link descriptive and spatial information for the analysis as a set of useful tool thanks to its ability to identify spatial connections between different information layers. With this method, created surfaces using Inverse Distance Weighting (IDW) method can be used to visualize, analyze, and understand spatial phenomena. In this geo-statistical method, it is substantially assumed that the rate of correlations and similarities between neighbors is proportional to the distance between them and can be defined as a distance reverse function of every point from neighboring points (Ozman Say et al. 2010, Ly et al. 2011).

Another method used in this study is cluster analysis. The cluster analysis arranges the sites into groups. Clusters are formed of sites that are similar in composition, as measured by a chosen ecological distance. Cluster analysis provides a summary of the similarity in species composition of various sites (Mooi and Sarstedt 2011).

\section{Results}

All results obtained from the air samples taken from 11 stations on the European side of Istanbul are presented in Tables and Figures. The culturable airborne bacteria concentration obtained from the stations after the incubation is presented in Table 2. The highest values $\left(1100 \mathrm{CFU} / \mathrm{m}^{3}\right.$ ) were measured in October 2009 at Bakirkoy station and Bahcelievler station (1 $\left.040 \mathrm{CFU} / \mathrm{m}^{3}\right)$. The lowest value was found to be $10 \mathrm{CFU} / \mathrm{m}^{3}$, which can be measured along the coastal stations during the winter months where rain and winds are effective.

As can be seen in Table 2, the lowest culturable airborne bacteria concentration values were found in winter months and the highest values were found in the fall and summer period although the values differed by stations.

In this study, culturable airborne bacteria level distribution of the study area was conducted using this geo-statistical method. Seasonal changes and transitions are statistically much more important and have been presented in Figures 2A, 2B, 2C and $2 \mathrm{D}$ in the form of GIS maps. The reference circle shown in the respective figures represented as $150 \mathrm{CFU} / \mathrm{m}^{3}$ is selected so as to make comparison of the values among the sampling stations. Districts have been limited with colors and seasonal averages of culturable airborne bacteria have been taken. To make a visual distinction, temperature changes, and cultural airborne bacteria concentrations have been identified on the same GIS maps.

Table 2. Concentrations of airborne bacteria $\left(\mathrm{CFU} / \mathrm{m}^{3}\right)$

\begin{tabular}{|c|c|c|c|c|c|c|c|c|c|c|c|}
\hline $\begin{array}{c}\text { Stations } \\
\text { Months }\end{array}$ & Atakoy & Yesilkoy & Menekse & Lagoon & Kcekmece & Taksim & Zeytinburnu & Avcilar & Bakirkoy & Bahcelievler & Eminonu \\
\hline January & 700 & 70 & 110 & 170 & 200 & 40 & 80 & 60 & 20 & 80 \\
\hline February & 60 & 40 & 80 & 120 & 80 & 60 & 10 & 20 & 20 & 60 & 60 \\
\hline March & 40 & 40 & 180 & 140 & 60 & 10 & 60 & 20 & 20 & 220 & 10 \\
\hline April & 10 & 20 & 40 & 10 & 20 & 70 & 20 & 50 & 40 & 50 & 70 \\
\hline May & 140 & 40 & 580 & 380 & 440 & 80 & 60 & 80 & 80 & 60 & 100 \\
\hline June & 80 & 80 & 220 & 120 & 500 & 80 & 100 & 120 & 180 & 200 & 320 \\
\hline July & 80 & 140 & 40 & 300 & 120 & 300 & 300 & 300 & 220 & 360 & 280 \\
\hline August & 340 & 250 & 220 & 360 & 140 & 420 & 340 & 400 & 400 & 480 & 400 \\
\hline September & 140 & 120 & 40 & 620 & 160 & 220 & 360 & 360 & 140 & 360 & 120 \\
\hline October & 20 & 180 & 200 & 60 & 180 & 460 & 240 & 220 & 1100 & 1040 & 300 \\
\hline November & 10 & 10 & 40 & 100 & 40 & 420 & 880 & 260 & 660 & 300 & 520 \\
\hline December & 80 & 60 & 80 & 160 & 60 & 40 & 100 & 40 & 60 & 100 & 140 \\
\hline MEAN & 140 & 90 & 150 & 210 & 170 & 180 & 210 & 160 & 250 & 280 & 200 \\
\hline
\end{tabular}


The Bray-Curtis similarity measure was chosen as the similarity coefficient and similarity matrices coupled with, culturable airborne bacteria concentration and station groups were generated. Bray-Curtis similarity index identified the pronounced differences among the sampling stations on the basis of the culturable airborne bacteria concentration. In the statistical analysis, with the exception of the Yesilkoy station,

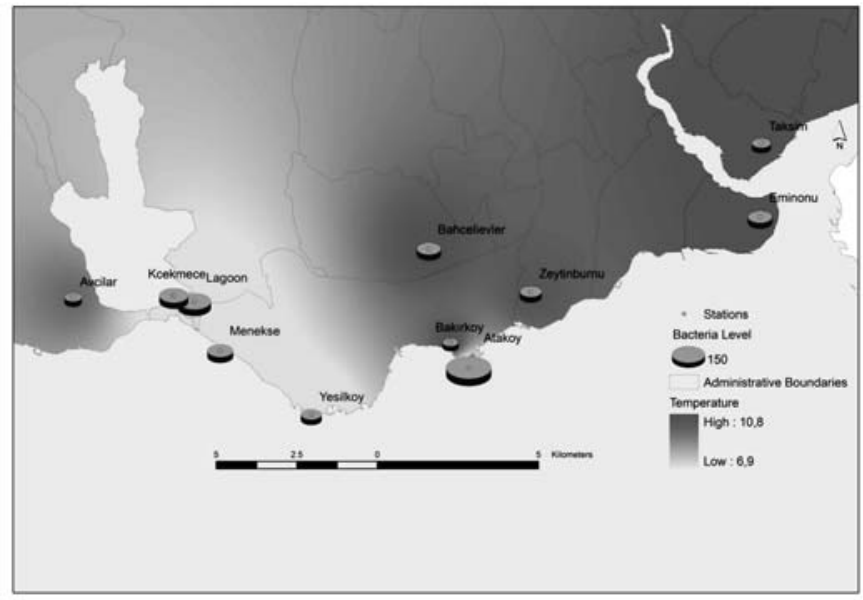

Fig. 2A. Temperature $\left({ }^{\circ} \mathrm{C}\right)$ and culturable airborne bacteria $\left(\mathrm{CFU} / \mathrm{m}^{3}\right)$ for winter

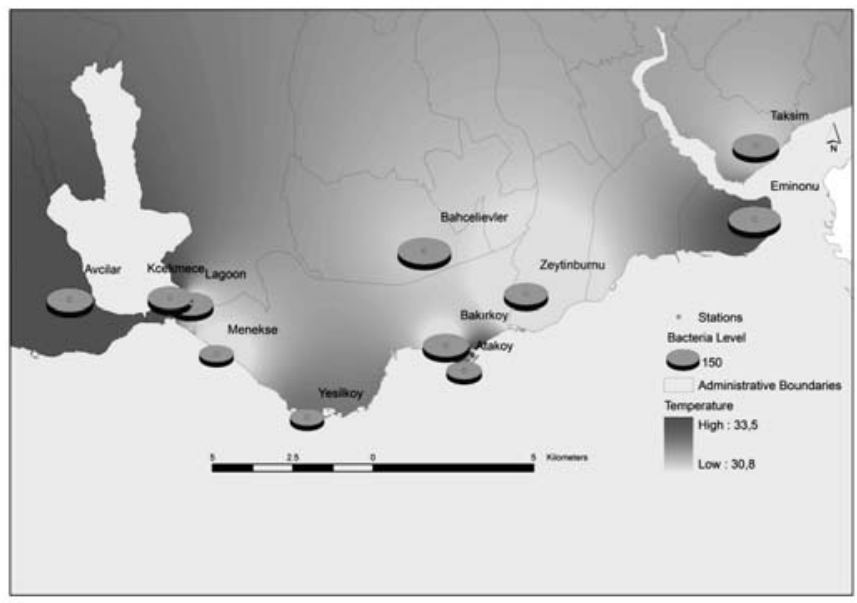

Fig. 2C. Temperature $\left({ }^{\circ} \mathrm{C}\right)$ and culturable airborne bacteria $\left(\mathrm{CFU} / \mathrm{m}^{3}\right)$ for summer the culturable airborne bacteria concentration can be seen in 4 different groups (Figure 3). These detected 4 different groups had group similarities with inland and shoreline stations with regards to culturable airborne bacteria concentrations. Especially in coastal regions, where urbanization levels are much lower, low culturable airborne bacteria concentrations were found. These coastal regions include Atakoy, Menekse

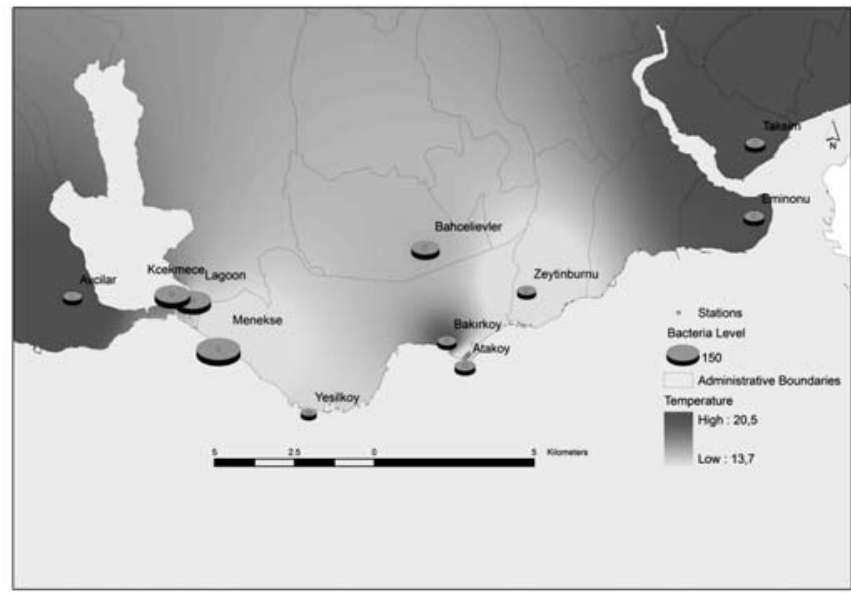

Fig. 2B. Temperature $\left({ }^{\circ} \mathrm{C}\right)$ and culturable airborne bacteria $\left(\mathrm{CFU} / \mathrm{m}^{3}\right)$ for spring



Fig. 2D. Temperature $\left({ }^{\circ} \mathrm{C}\right)$ and culturable airborne bacteria $\left(\mathrm{CFU} / \mathrm{m}^{3}\right)$ for autumn



Fig. 3. Bray-Curtis similarity dendrogram for culturable airborne bacteria concentration 
and Avcilar. As a result of application of Bray-Curtis, the second group (Bahcelievler-Bakirkoy) is identified as inland. The two other groups, first is Eminonu-Zeytinburnu-Lagoon and the second is (Taksim-Kcekmece) had similarities with stations in inland and shoreline characterization, respectively.

According to the disc diffusion test and PCR for mecA gene, 15 methicillin-resistant staphylococci $(11.4 \%)$ were isolated. The diversity of the species identified by conventional methods is shown in Table 3. It was approved to grade the values from the highest value of MAR index to the lowest value in the table. While the highest values are seen in Taksim station (0.5), and some other higher values in Eminonu and Avcilar station (0.4), no methicillin-resistant staphylococci were found in Yesilkoy and Atakoy shoreline stations. As can be seen in Table 3, it was found out that Taksim, Eminonu and Avcilar, among the inland areas, had the highest MAR value in summer and spring months. The high values in bacteria numbers in similar periods also belong to these stations.

The stations with sensitivity to other antimicrobial agents and MAR indexes of isolates that were determined to be phenotypically and genotypically resistant to methicillin have been presented in the same table. With regards to public health, in stations where MAR index reached higher values than 0.2, Bray-Curtis similarity analysis was used to reveal the difference of other stations (Figure 4). However, in terms of the MAR index, the same stations were evaluated and 3 different groups were determined. In terms of MAR index, high similarities for Taksim, Eminonu, Avcilar and Lagoon were found, especially for MAR values higher than 0.2. Similar values were found for Zeytinburnu, Kcekmece and Menekse stations, which are overpopulated, dense, and distant from the coast, and lack green areas. However, Bahcelievler, Bakirkoy, Yesilkoy and Atakoy stations are the station group in which staphylococci isolates were not determined during the sampling period.

\section{Discussion}

In studies conducted outdoors, significant differences in the recovery number of environmental bacteria have been observed in city centers, agricultural areas, coastal regions, village lots, and even different coordinates within the same location. Furthermore, it is known that building structures, unplanned urbanization, traffic and dense population play a role in bacteria concentration. Many studies have demonstrated that such factors as temperature, moisture, rainfall, pressure, wind speed, relative humidity, and seasonal and hourly changes in sunlight lead to changes in bacterial concentrations (Sarica et al. 2002, Zhu et al. 2003, Fang et al. 2008, Mentese et al. 2009, Güneş 2009, Yassin and Almouqatea 2010). However, the main aim of this study was not to reveal the bacterial concentration but to determine the antimicrobial susceptibilities of methicillin-resistant staphylococci, which are of importance in terms of

Table 3. Origin of isolates and species distribution of the Staphylococci

\begin{tabular}{|c|c|c|c|c|c|c|c|c|c|c|c|c|c|}
\hline Stations & Months & Species & CF & P & DO & IPM & T & S & AMC & VA & G & CD & MAR \\
\hline Taksim & April & S. hominis & R & R & R & S & R & S & S & S & S & R & 0.5 \\
\hline Avcilar & January & S. hominis & R & R & R & S & R & S & S & S & S & S & 0.4 \\
\hline Eminonu & June & S. hominis & S & R & R & S & R & S & S & S & S & R & 0.4 \\
\hline Taksim & August & S. hominis & S & R & I & S & R & S & S & S & S & S & 0.3 \\
\hline Lagoon & April & S. hominis & S & R & S & S & S & I & S & S & R & R & 0.3 \\
\hline Avcilar & October & S. hominis & S & R & R & S & R & S & S & S & S & S & 0.3 \\
\hline Zeytinburnu & June & S. capitis spp. capitis & S & S & S & S & S & R & S & S & S & S & 0.1 \\
\hline Avcilar & June & S. cohnii spp. cohnii & S & R & S & S & S & S & S & S & S & S & 0.1 \\
\hline Menekse & September & S. sciuri & S & R & S & S & S & S & S & S & S & I & 0.1 \\
\hline Menekse & October & S. hominis & S & R & S & S & S & S & S & S & S & S & 0.1 \\
\hline Eminonu & March & S. cohnii spp. cohnii & S & R & S & S & S & S & S & S & S & S & 0.1 \\
\hline Kcekmece & March & S. hominis & S & R & S & S & S & S & S & S & S & S & 0.1 \\
\hline Zeytinburnu & April & S. hominis & S & S & S & S & S & S & S & S & S & S & 0 \\
\hline Kcekmece & October & S. hominis & S & S & S & S & S & S & S & S & S & S & 0 \\
\hline Taksim & December & S. hominis & S & S & S & S & S & S & S & S & S & S & 0 \\
\hline
\end{tabular}

CF = ciprofloxacin $(5 \mu \mathrm{g}), \mathrm{P}=$ penicillin $(10 \mu \mathrm{g}), \mathrm{DO}=$ doxycycline $(30 \mu \mathrm{g}), \mathrm{IPM}=$ imipenem $(10 \mu \mathrm{g})$,

$\mathrm{T}=$ tetracycline $(30 \mu \mathrm{g}), \mathrm{S}=$ streptomycin $(10 \mu \mathrm{g}), \mathrm{AMC}=$ amoxicillin/clavulanic acid $(20-10 \mu \mathrm{g})$,

$\mathrm{VA}=$ vancomycin $(30 \mu \mathrm{g}), \mathrm{G}=$ gentamicin $(10 \mu \mathrm{g}), \mathrm{CD}=$ clindamycin $(2 \mu \mathrm{g})$,

Gentamicin and streptomycin : aminoglycosides

Tetracycline and doxycycline : tetracyclines

Ciprofloxacin : fluoroquinolones

Penicillin : penicillins

Amoxicillin/clavulanic acid: $\beta$-lactam/ $\beta$-lactamase inhibitor combinations

Imipenem : carbapenems

Vankomycin : glycopeptides

Clindamycin : lincosamides

$\mathrm{S}=$ Susceptible, $\mathrm{I}$ = Intermediate resistant, $\mathrm{R}=$ Resistant 


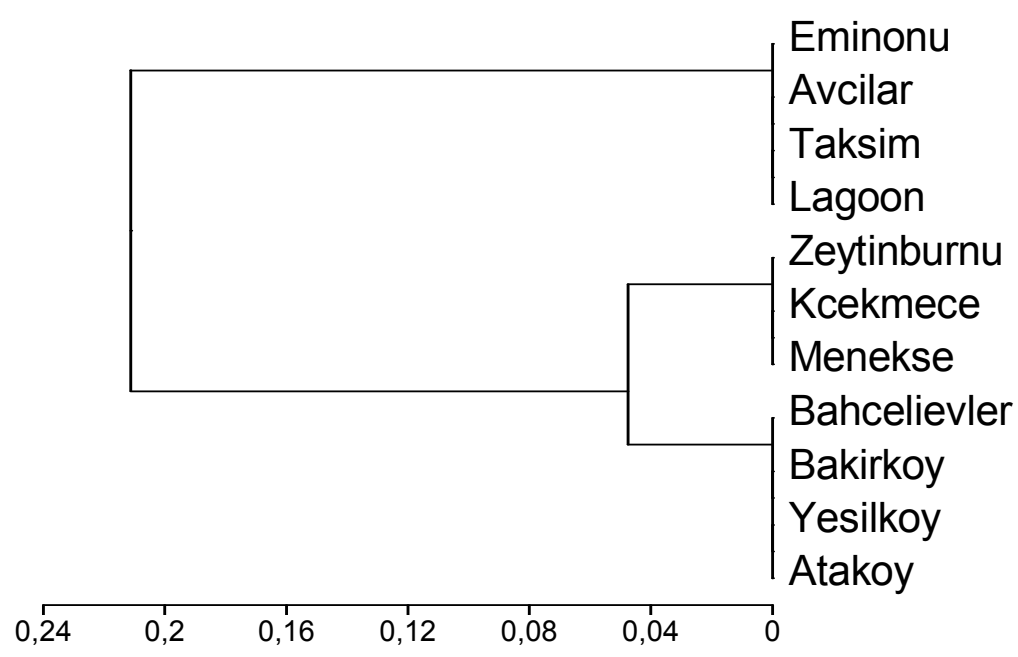

Fig. 4. Bray-Curtis similarity dendrogram for MAR index (three categories)

public health. This is because of the fact that in other countries, studies and models related to outdoor bacterial concentrations and triggering factors have been completed and now studies on species identification and molecular microbiology which are important for public health are taken into consideration. In the present study, the data of outdoor environments culturable airborne bacteria concentrations, the lack of which is deeply felt in Turkey, were shared and the data related to antimicrobial susceptibilities of methicillin-resistant staphylococci which comprise the main aim of the study were interpreted.

In their study conducted in the city center of Marseille, Giorgio et al. (1996) measured the average bacteria concentration to be $791 \pm 598$ bacteria $/ \mathrm{m}^{3}$ and they also found out that air based bacteria increased with temperature and wind speed (Giorgio et al. 1996). Bovallius et al. (1978) conducted a study in Sweden for over a 3 year period and reported the average bacteria concentration for agricultural areas to be $99 \mathrm{CFU} / \mathrm{m}^{3}, 63 \mathrm{CFU} / \mathrm{m}^{3}$ for the shoreline, and $850 \mathrm{CFU} / \mathrm{m}^{3}$ for the city center. The average concentration of total culturable microorganisms of $3.7 \times 10^{3} \pm 2.1 \times 10^{2}$ (standard deviation) $\mathrm{CFU} / \mathrm{m}^{3}$ at three selected sampling sites in Beijing was noted by Fang et al. (2008). They reported values between 71 and $22100 \mathrm{CFU} / \mathrm{m}^{3}$ in the city of Beijing, China, and values between 2 and $8500 \mathrm{CFU} / \mathrm{m}^{3}$ for other urban environments (Fang et al. 2007). In another study regarding the number of airborne bacteria, the emphasis was put on the differences between rural and forest sites. The highest average number of bacteria during daylight hours was exhibited at the urban site $\left(609 \mathrm{CFU} / \mathrm{m}^{3}\right)$, the forest site $\left(522 \mathrm{CFU} / \mathrm{m}^{3}\right)$, and the rural site $\left(242 \mathrm{CFU} / \mathrm{m}^{3}\right)$, respectively. Starting with the lowest concentration, in general, concentrations tend to increase at sunrise, decrease during the solar noon hours, gradually increase until sunset, and then decrease in the evening, with the lowest concentrations occurring between 21:00 and 05:00 hours. Pigmented bacteria represented anywhere between $21-62 \%$ of the total bacteria samples with the highest percentage of pigmented bacteria found at the rural site, and the lowest at the forest site (Shaffer and Lighthart 1997). The concentration of culturable bacteria in outdoor particulate highly dependent on factors such as the type of environment or the atmospheric conditions is not always reliable (Gandolfi et al. 2011). Numerous studies have been conducted in order to determine the concentration distribution of airborne microorganisms in outdoor environments. The concentration of microbes in the air is affected by several factors, including daily and seasonal meteorological variations, vegetation, air pollution, agricultural, industrial, and other human activities (Pasanen et al. 1991, Klaric and Pepeljnjak 2006, Fang et al. 2007, Fang et al. 2008, Rogula-Kozłowska et al., 2013). Compared to other cities (Beijing, Marseille, Tokyo etc.) in the world, the bacterial concentration was lower in the city center of Istanbul (Giorgio et al. 1996, Fang et al. 2007, Gandolfi et al. 2011). In literature review, no similar follow up studies were found for Turkey. However, Mentese et al. (2009) conducted a study in Ankara Province where they examined changes in both culturable airborne bacteria and fungus concentrations.

In this study, when compared to other stations, the effect of geographical locations on the distribution of airborne bacteria numbers was found to be much higher in densely populated areas and in the areas distant to coastline. The culturable airborne bacteria concentrations were found to be low for the Yesilkoy and Atakoy stations. These low concentration levels have been attributed to the lack of urban settlements, sparse traffic flow, and sufficient amounts of green areas within the vicinity of these stations. In addition, the distinction of the Yesilkoy station from other 4 different groups determined by statistical analysis (Figure 3 ) indicates that there is a difference between inland and shoreline stations in terms of culturable airborne bacteria concentrations; this finding is also supported by the literature. Traffic flow (both human and vehicle), and human activities and vegetation coverage are usually considered to be the main contributing factors in concentration distribution of airborne microorganisms in outdoor environments (Seino et al. 2005, Fang et al. 2008). They are regarded as the predominant sources of airborne microorganisms in outdoor environments. Our results (Table 2) demonstrated that the concentration distribution of the sampling stations was similar to the literature results.

The coagulase negative staphylococci (CoNS) are the major component of the normal microbial communities of the human body, and are common inhabitants of the upper airways and skin. It has been suggested that the main emission sources of staphylococci to air are inhabitants, because of the fact that the natural microflora of human organisms contains numerous 
Staphylococcus species. During daily activities, people shed these microflora components in their surroundings. Previously, especially when CoNS used to be considered as important, the apparent increase in the incidence and prevalence of coagulase negative species, which tend to have multiple resistances, has drawn great attention. Today, CoNS are in the third place among nosocomial infections. More importantly, most of these species are resistant to methicillin, which also refers to the fact that they are resistant to other beta-lactam antibiotics at the same time. It is also known that methicillin resistance in CoNS plays a role in transferring to other CoNS (Szewczyk et al. 2003, Szewczyk et al. 2004, Lis et al. 2009, Bagcigil et al. 2012). Due to the known importance of staphylococci and methicillin resistance in public health, apart from studying culturable airborne bacteria, investigations of methicillin resistant $S$. aureus MRSA were also targeted during this study. It is optimistic that MRSA, which take the lead in nosocomial infections, were not found. However, methicillin resistant coagulase negative staphylococci were found at the rate of $11.4 \%$. When seasons are combined with other negative environmental factors and people with suppressed immune systems are in the same environment with these high bacteria ratios, it should be remembered that this could lead to important health problems.

Mentese et al. (2009) determined many aerosol agents in the air samples they collected from different districts in Ankara. Among these samples, they also found and isolated different CoNS species along with the $S$. hominis species, which is considered to be a potential pathogen that penetrates into and inhabits the body when the body's defense systems are weak. Due to the limited number of studies pertaining to airborne bacteria, studies related to MRCoNS were not found. As this study does not cover all Staphylococcus species and focuses on the identification of those that are methicillin-resistant, it was impossible to compare the results with other studies. Nevertheless, the dominant species found in this study was determined to be the $S$. hominis (Table 3 ). In many studies conducted on animals or animal products, multiple antibiotic resistance in CoNS species and high ratios of resistance for glycopeptide antimicrobials are noted (Abulreesh and Organjii 2011 Bagcigil et al. 2012). In this study, antibiotic resistance for air based isolates was found at $26.7 \%$. While the ratios were lower in studies conducted in clinical settings or closed environments, which can be thought of as a positive result, it was an interesting result to see that all of the isolates belonged to S.hominis, which is considered to play an important role in nosocomial infections.

One of the most striking studies pertaining to bacterial counts in urban areas and crowded environments was conducted in different areas of Bangladesh. This study was carried out for 12 months and seasonal differences were reported; bacterial prevalence was reported to be $82.52 \%$. The most frequently isolated organisms throughout the seasons were noted to be S. aureus, Bacillus cereus, and B. subtilis (Bhowmick and Rashid 2004). In a study conducted in Poland, both sampling methodologies were compared and all isolated $S$. aureus and S. epidermidis bacteria ratios were found to be $627 \mathrm{CFU} / \mathrm{m}^{3}$ (Zmysłowska and Jackowska 2005). In this study, throughout the sampling period, only $15(11.4 \%)$ MRCoNS were isolated from all of the samples collected from 11 stations. In samples from 4 of the stations, no MRCoNS were isolated. In addition, the lowest values from the culturable airborne bacteria concentrations found at these stations were used throughout the sampling period. Of these stations, which are located in the southwest coastal area, only two have walking areas and are open to the public. With fewer inhabitants, various green areas, and the suitability of environmental conditions the usability of these areas for recreational purposes increases.

However, in terms of the MAR index, the same stations evaluated identically and 3 different groups were determined (Figure 4). The multiple antimicrobial resistance index (MAR) is helpful to analyze health risks and it is used to check antimicrobial resistance. In terms of MAR index, high similarities for Taksim, Avcilar and Eminonu were found, especially for MAR value higher than 0.2. The potential hazard caused by bioaerosol depends on the pathogenicity of a specific microorganism as well as other factors such as the environmental conditions, which determine the survival of the microorganisms in the air (Mohr 2002). Meteorological conditions (especially wind speed and direction) direct airborne dispersion from the emission points, which follows the pathway and enters the body and also triggers an immunologic response via the potential receptor (Sánchez-Monedero et al. 2008). Not only medical doctors but also legal administrative authorities should consider the results obtained in these stations with regards to public health.

\section{Conclusions}

In summary, the distribution patterns of differing types of microbes might have a close relationship with the microbial source in nature. Therefore, microbial source characteristics at different sampling sites should be investigated in detail. Similarly, future bioaerosol sampling studies need to be performed under a variety of environmental conditions in order to assess the impact of the environment on microbial bioaerosol patterns and associated human health risks. Therefore, for future investigations, it will be important to find the potential relationships between size distribution patterns of bio-aerosols and associated human respiratory diseases.

Antibiotic resistance of staphylococci is the major public health concern since the bacteria can be easily circulated in the metropolitan areas of the world. For this reason, in studies with lower culturable airborne bacteria concentrations and CoNS, the importance of being in coastal recreational areas has been emphasized especially in terms of human health. Trends in this study data suggest that resistant strains were available with higher concentrations in inland stations compared to shoreline stations. The findings of the present study, in combination with existing literature documenting the increase in community acquired infections caused by resistant strains of staphylococci, indicate the need for further research on the role that aerosolized organisms play in the causation of adverse health of occupants in residential buildings areas. Although this might be simply attributed to a bias in the submission of sequences to databases, as $S$. aureus is the most studied among staphylococci, a substantial homology in genes harbored by environmental and clinical species can be inferred. For this reason, despite the relatively low abundance of antibiotic resistance determinants in airborne Staphylococcus species, such homology remarks that the study of clinical and human-associated microorganisms is not enough when the topic of concern is related to human health, but also environmental 
microorganisms should be carefully considered. Furthermore, within the light of the results of the present study, it can be said that especially city planners and legal or administrative authorities should attach more importance to green areas, parks and walking paths in their planning. In order to perform nature walks being one of the fundamental principles of a healthy life, it can be recommended that settlements should be away from areas with crowded populations and heavy traffic load. Projects which aim to increase these areas of such nature should be developed and materialized and constant monitoring of the current areas should be done regularly.

\section{Acknowledgments}

This study was supported by the Research Fund of The University of Istanbul (Project Number: 2917/2008 and UDP-35903). Special thanks to the IUCEMIK Group for their assistance with the field work. We gratefully acknowledge Dr. N. Linda FRAIM and Armagan OZER for critical reading of the manuscript.

\section{References}

Abulreesh, H.H. \& Organjii, S.R. (2011). The prevalence of multidrug resistant staphylococci in food and the environmental of Makkah, Saudi Arabi, Research Journal of Microbiology, 6 (6), pp. 510-523.

Aydogdu, H., Asan, A., Otkun, M.T. \& Ture, M. (2005). Monitoring of fungi and bacteria in the indoor air of primary schools in Edirne City, Turkey, Indoor and Built Environment, 14, pp. 411-425.

Aydogdu, H. \& Asan, A. (2008). Airborne fungi in child day care centers in Edirne City, Turkey, Environmental Monitoring and Assessment, 147(1-3), pp. 423-444.

Aydogdu, H., Asan, A. \& Otkun, M.T. (2010). Indoor and outdoor airborne bacteria in child day-care centers in Edirne City (Turkey), seasonal distribution and influence of meteorological factors, Environmental Monitoring and Assessment, 164, pp. 53-66.

Bagcıgil, A.F., Ikiz, S., Güzel, Ö., Parkan, Ç. \& Ilgaz, A., (2012). Species distribution of methicillin resistant staphylococci isolated from animals, environmental samples and staffs, Journal of the Faculty of Veterinary Medicine, Istanbul University, 38(2), pp. 151-160.

Bhowmick, B.K. \& Rashid. H. (2004). Bacteriological study of Chittagong City Area, Pakistan Journal of Biological Sciences, 7(9), pp. 1616-1619.

Bovallius, A., Bucht, B., Roffey, R. \& Anas, P. (1978). Three-year investigation of the natural airborne bacterial flora at four localities in Sweden, Applied and Environmental Microbiology, 35(5), 847-852.

Bowers, R.M., Lauber, C.L., Wiedinmyer, C., Hamady, M., Halar, A.G., Fall, R., Knight, R. \& Fierer, N. (2009). Characterization of airborne microbial communities at a high-elevation site and their potential to act as atmospheric ice nuclei, Applied and Environmental Microbiology, 75 (15), 5121-5130.

Bowers, R.M., McLetchie, S., Knight, R. \& Fierer, N. (2010). Spatial variability in airborne bacterial communities across land-use types and their relationship to the bacterial communities of potential source environments, International Society for Microbial Ecology (ISME), 5, pp. 601-612.

Bowers, R.M., Sullivan, A.P., Costello, E.K., Collett, J.L., Knight, R. $\&$ Fierer, N. (2011). Sources of bacteria in outdoor air across cities in the midwestern United States, Applied and Environmental Microbiology, 77 (18), 6350-6356.

Brodie, E.L., DeSantis, T.Z., Parker, J.P. M., Zubietta, I.X., Piceno, Y.M. \& Andersen, G.L. (2007). Urban aerosols harbor diverse and dynamic bacterial populations, Proceedings of the National Academy of Sciences USA, 104 (1), pp. 299-304.

Chitanand, M.P, Kadam, T.A., Gyananath, G., Totewad, N.D. \& Balhal, D.K. (2010). Multiple antibiotic resistance indexing of coliforms to identify high risk contamination sites in aquatic environment, Indian Journal of Microbiology, 50, pp. 216-220.

Clinical and Laboratory Standards Institute (CLSI), 2013. Performance Standards for Antimicrobial Susceptibility Testing; Twenty-Third Informational Supplement. CLSI document M100-S23 (ISBN 1-56238-866-5 [electronic]).

Fang, Z., Ouyang, Z., Zheng, H., Wang, X. \& Hu, L. (2007). Culturable airborne bacteria in outdoor environments in Beijing, China, Microbial Ecology, 54, pp. 487-496.

Fang, Z., Ouyang, Z., Zheng, H. \& Wang, X. (2008). Concentration and size distribution of culturable airborne microorganisms in outdoor environments in Beijing, China, Aerosol Science and Technology, 42:5, pp. 325-334.

Gandolfi, I., Franzetti, A., Bertolini, V., Gaspari, E. \& Bestetti, G. (2011). Antibiotic resistance in bacteria associated with coarse atmospheric particulate matter in an urban area, Journal of Applied Microbiology 110(6), pp. 1612-1620.

Geha, D.J., Uhl, J.R., Gustaferro, C.A. \& Persingi, D.H. (1994). Multiplex PCR for identification of methicillin-resistant staphylococci in the clinical laboratory, Journal of Clinical Microbiology, 32(7), pp. 1768-1772.

Giorgio, C.D., Krempff, A., Guiraud, H., Binder, P., Tiret, C. \& Dumenil, G. (1996). Atmospheric pollution by airborne microorganisms in the city of Marseilles, Atmospheric Environment, 30(1), pp. 155-160.

Güneş, S. (2009). Indoor and Outdoor Airborne Bacterial Concentrations in the Different Regions of Istanbul. MSc. Thesis, Istanbul University, Istanbul, Turkey, 83 pages. (in Turkish)

Huebner, J. \& Goldmann, D.A. (1999). Coagulase-negative staphylococci: role as pathogens, Annual Review of Medicine, 50(1), pp. 223-236.

ISO/FDIS 14698-1, 2003. Cleanrooms and associated controlled environments - Biocontamination control - Part 1: General principles and methods, General principles and methods. (http:// www.icccs.net/news/ContamCtrlStdsSchicht.pdf (03.2013)).

Istanbul Metropolitan Municipality Annual Report for 2012, 2013. IMM Department of Financial Services - Directorate of Strategic Planning. Pasifik Ofset, (http://www.ibb.gov.tr/en-US/ Documents/annual_reports/IMM-2012.pdf(04.2013)).

Istanbul Metropolitan Municipality Annual Report for 2013, IMM Department of Financial Services - Directorate of Strategic Planning (http://www.ibb.gov.tr/tr-R/BilgiHizmetleri/Yayinlar/ FaaliyetRaporlari/Documents/2013/iBB_CD_PDF_2014/cevre_ yesilalan_204-210.pdf (02.2014)).

Karwowska, E., Miaśkiewicz-Pęska, E., Andrzejewska-Morzuch, E. (2013). Microbiological air contamination in premises of the primary health-care, Archives of Environmental Protection, 39 (4), pp. 51-58.

Klaric, M.S. \& Pepeljnjak, S. (2006). A year-round aeromycological study in Zagreb Area, Croatia, Annals of Agricultural and Environmental Medicine, 13, pp. 55-64.

Koneman, E.W., Allen, S.D., Janda, W.M., Schreckenberger, P.C. \& Winn, W.C. (1997). Chapter II: The Gram positive cocci in Part I: Staphylococci and related organisms. In: Color Atlas and Textbook of Diagnostic Microbiology, $5^{\text {th }}$ ed., Lippincott, Philadelphia, New York, pp. 539-555.

Lis, D.O., Pacha, J.Z. \& Idzik, D. (2009). Methicillin resistance of airborne coagulase-negative staphylococci in homes of persons having contact with a hospital environment, American Journal of Infection Control, 37(3), pp. 177-182.

Ly, S., Charles, C. \& Degre, A. (2011). Geostatistical interpolation of daily rainfall at catchment scale: the use of several variogram 
models in the Ourthe and Ambleve catchments, Belgium, Hydrology and Earth System Science, 15, pp. 2259-2274.

Magiorakos, A.P., Srinivasan, A., Carey, R.B., Carmeli, Y., Falagas, M.E., Giske, C.G., Harbarth, S., Hindler, J.F., Kahlmeter, G., Olsson-Liljequist, B., Paterson, D.L., Rice, L.B., Stelling, J., Struelens, M.J., Vatopoulos, A., Weber, J.T. \& Monnet, D.L. (2012). Multidrug-resistant, extensively drug-resistant and pandrug-resistant bacteria: an international expert proposal for interim standard definitions for acquired resistance, Clinical Microbiology and Infection, 18(3), pp. 268-281.

Mandal, J. \& Brandl, H. (2011). Bioaerosols in indoor environment - A review with special reference to residential and occupational locations, The Open Environmental \& Biological Monitoring Journal, 4, pp. 83-96.

Mentese, S., Rad, A.Y., Arısoy, M. \& Gullu, G. (2009). Spatial variation of bioaerosol levels in the urban atmosphere of Ankara, Ecology, 19 (73), pp. 21-28.

Mentese, S., Rad, A.Y., Arısoy, M. \& Gullu, G. (2012). Seasonal and spatial variations of bioaerosols in indoor urban environments, Ankara, Turkey, Indoor Built Environment, 21, pp. 797-810.

Mohr, A.J. (2002). Fate and transport of microorganisms in air. In: Manual of Environmental Microbiology, Hurst, C.J. (ed.) $2^{\text {nd }} e d$. ASM Press, Washington, pp. 827-838.

Mooi, E. \& Sarstedt, M. (2011). A Concise Guide to Market Research. In: Chapter 9, Cluster Analysis, DOI 10.1007/978-3-642-125416_9, Springer-Verlag, Berlin Heidelberg 2011.

NCCLS, 1997. Methods for Dilution, Antimicrobial Susceptibility Tests for Bacteria that Grow Aerobically - Fourth Edition, Approved Standard. NCCLS document M7-A4 (ISBN1-56238-309-4).

NCCLS, 2004. Performance standards for antimicrobial disk and dilution tests for bacteria isolated from animals; Informational supplement. NCCLS document M31-S1 (ISBN1-56238-534-8).

Ozman Say, A.N., Sivri, N., Erturk, A., Seker, D.Z. \& Fuseng, L. (2010). Analysis of Phytoplankton Distribution at the Southwestern Coast of Istanbul Utilizing GIS, Fresenious Environmental Bulletin, 19 (9B), pp. 2116-2122.

Pasanen, A.L., Pasanen, P., Jantunen, M.J. \& Kalliokoski, P. (1991). Significance of air humidity and air velocity for fungal spore release into the air. Atmospheric Environment Part A-General Topics, 25, pp. 459-462.

Roberts, B.A., Lencastre, W., Eisner, E.P., Severina, B., Shopsin, B.N., Kreiswirth, A. \& Tomasz, A. (1998). Molecular epidemiology of methicillin-resistant Staphylococcus aureus in 12 New York Hospitals, Journal of Infectious Diseases, 178, pp. 164-171.

Rogula-Kozłowska, W., Kozielska B., Klejnowski K. \& Szopa, S. (2013). Hazardous compounds in urban PM in the central part of upper Silesia (Poland) in winter, Archives of Environmental Protection, 39 (1), pp. 53-65.
Sánchez-Monedero, M.A., Aguilar, M.I., Fenolla, R. \& Roig, A. (2008). Effect of the aeration system on the levels of airborne microorganisms generated at wastewater treatment plants, Water Research, 42, pp. 3739-3744.

Sarica, S., Asan, A., Tatman, M.O. \& Ture, M. (2002). Monitoring indoor airborne fungi and bacteria in the different parts of Trakya University Hospital (Edirne-Turkey), Indoor Built Environment, 11, pp. 285-292.

Seino, K., Takano, T., Nakamura, K. \& Watanabe, M. (2005). An evidential example of airborne bacteria in a crowded, underground public concourse in Tokyo, Atmospheric Environment, 39, pp. 337-341.

Shaffer, B.T. \& Lighthart, B. (1997). Survey of culturable airborne bacteria at four diverse locations in Oregon: urban, rural, forest, and coastal, FEMS - Federation of European Microbiological Societies Microbiology Ecology, 34, pp. 167-177.

Shiomori, T., Miyamotoy, H., Makishima, K., Yoshida, M., Fujiyoshi, T., Udaka, T., Inaba, T. \& Hiraki, N. (2002). Evaluation of bedmaking-related airborne and surface methicillin-resistant Staphylococcus aureus contamination, Journal of Hospital Infection, 50, pp. 30-35.

Simor, A.E., Ofner-Agostini, M., Bryce, E., McGeer, A., Paton, S. \& Mulvey, M.R. (2002). Epidemiology committee and Canadian nosocom laboratory. characterization of methicillin-resistant Staphylococcus aureus in Canadian hospitals, results of 5 years of national surveillance, 1995-1999, Journal of Infectious Diseases, 186, pp. 652-660.

Skoog, J. (2006). Relative air humidity in hospital wards - user perception and technical consequences, Indoor Built Environment, 15(1), pp. 93-97.

Szewczyk, E.M., Nowak, T., Cieślikowski, T. \& Różalska, M. (2003). Potential role of Staphylococcus cohnii in a hospital environment, Microbial Ecology in Health and Disease, 15, pp. 51-56.

Szewczyk, E.M., Różalska, M., Cieślikowski, T. \& Nowak, T. (2004). Plasmids of Staphylococcus cohnii isolated from the intensive-care unit, Folia Microbiology, 49(2), pp. 123-131.

TUIK (Turkey Statistical Institute), 2013. Selected Indicators for Istanbul, 2012, ISSN 1307-0894; ISBN978-975-19-5761-0 (http:// www.tuik.gov.tr/ilGostergeleri/iller/ISTANBUL.pdf (02.2014)).

Yassin, M.F. \& Almouqatea, S. (2010). Assessment of airborne bacteria and fungi in an indoor and outdoor environment, International Journal of Environmental Science and Technology, 7(3), pp. 535-544.

Zhu, H., Phelan, P.E., Duan, T., Raupp, G.B., Fernando, H.J.S. \& Che, F. (2003). Experimental study of indoor and outdoor airborne bacterial concentrations in Tempe, Arizona, USA, Aerobiologia, 19, pp. 201-211.

Zmysłowska, I. \& Jackowska, B. (2005). The occurrence of the airborne bacteria genus Staphylococcus in the city of Olsztyn, Archiwum Ochrony Środowiska, 31, pp. 13-24. 